International Journal of Pediatric Research and Reviews
(ISSN:2637-4978)

\title{
Sensory integration therapy (SIT) in the assistance to child population: integrative literature review
}

\author{
Maria Gisele Cavalcanti de Oliveira1*; Vanessa dos Santos Nunes²; Sara Maria Xavier da \\ Cruz $^{3}$; Isvania Maria Serafim da Silva Lopes ${ }^{4}$. \\ ${ }^{1}$ UFPE; ${ }^{2}$ UFPE; ${ }^{3}$ UFPE; ${ }^{4}$ UFPE.
}

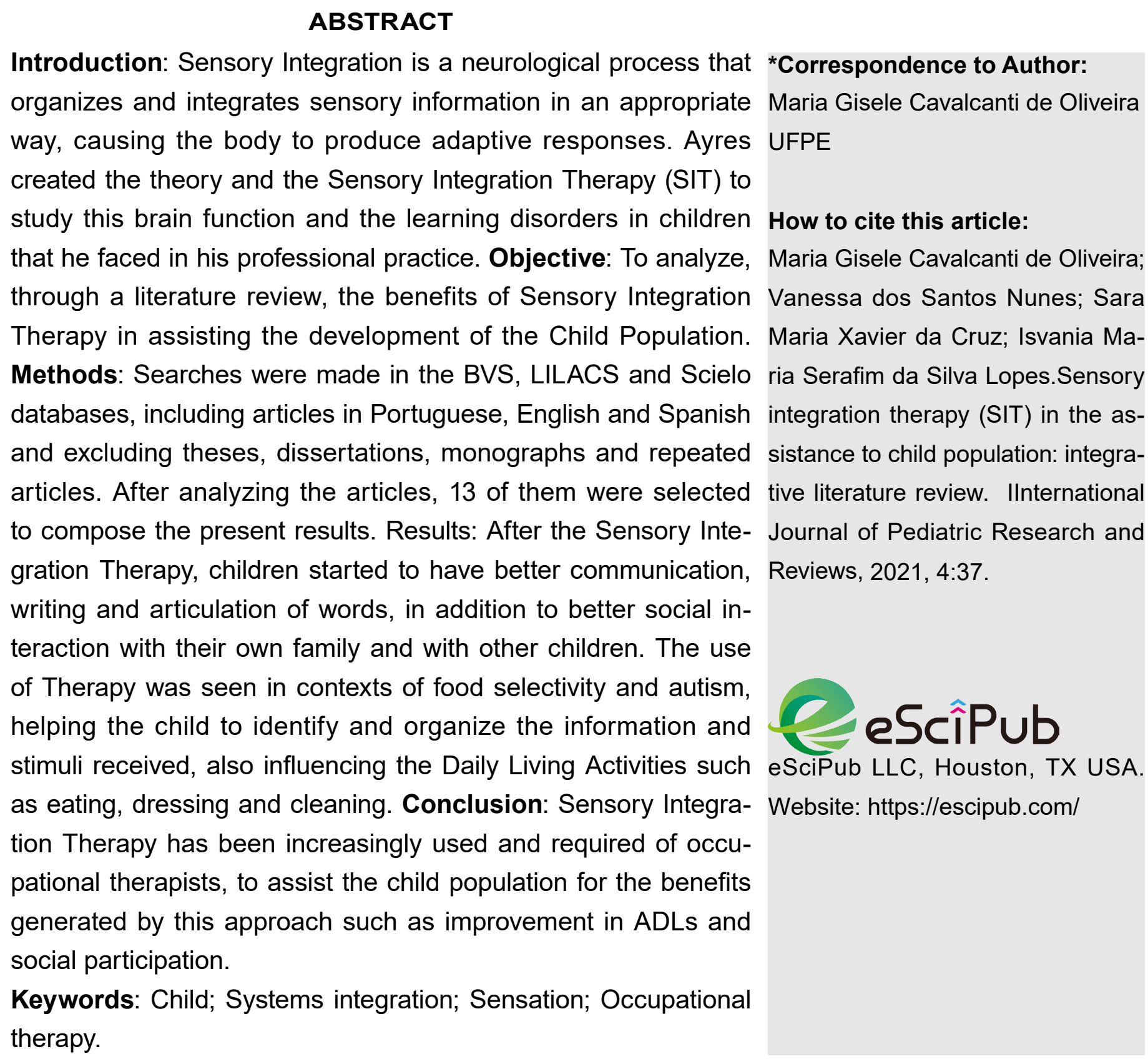




\section{INTRODUCTION}

According to Anna Jean Ayres, a North American occupational therapist, Sensory Integration is a neurological process that organizes and integrates sensory information in an appropriate way, making the body produce an adaptive response, in such a way that it is successful for itself and to the environment ${ }^{[1]}$. According to Ayres, the primary function of neurons is to transport information about the body and environment, through sensory receptors, to trigger harmonious motor actions and favor successful child neurodevelopment ${ }^{[2]}$. Sensory Processing is a neurophysiological function that is configured in how the body receives and interprets the sensory stimuli that arrive at all times ${ }^{[2]}$.

The Sensory Integration Theory (SIT) was developed from Anna's clinical practice, attending children with various comorbidities, to explain the relationship between the neurological processing of sensory stimuli and the learning disorders present in her patients ${ }^{[3]}$. SIT, created from theory, consists of facilitating the integration of sensations, seeking normal patterns of adaptive responses through various activities, without requiring complex motor planning that has not yet been learned. In addition, the child's internal motivation is also used in SIT, that is, the child's engagement in significant activities so that the therapy is pleasurable $e^{[4]}$.

Miller et a ${ }^{5}$ proposed, based on data published by Ayres herself, a classification to facilitate the understanding of changes in Sensory Processing. The study presents three types of Sensory Processing Disorder (SPD): Sensory Modulation Disorder (SMD) which is divided into hyperresponsiveness, hyporesponsiveness or sensory search; Sensory Based Motor Disorder (SBMD), where are Dyspraxia and Postural Disorders and finally Sensory Discrimination Disorders (SDD) that can be visual, tactile, vestibular, auditory, olfactory or proprioceptive.
With the help of this classification, it was possible for occupational therapists to incorporate SIT more frequently in various diagnoses in the child population and not only in cases where there was impairment in Daily Life Activities, school, or social, caused by disorders of learning. Some examples of other comorbidities in which this approach is used are Autism Spectrum Disorder (ASD), Attention Deficit Hyperactivity Disorder (ADHD) and Food Selectivity ${ }^{6}$. Based on this, the objective is to analyze, through a literature review, the benefits of Sensory Integration Therapy in assisting the development of the child population.

\section{METHODS}

It is an Integrative Literature Review, through the search for articles in the LILACS and Virtual Health Library (BVS) databases. In the research, the following descriptors were used: "child", "systems integration", "sensation", "therapy" and "occupational therapy", which were crossed 2 by 2 with each other, such as: "child" AND " therapy "until all descriptors were combined.

Initially, the articles were sorted by titles. For this selection, the inclusion criteria established were: articles in Portuguese, English or Spanish; full text available free of charge and articles presenting Sensory Integration Therapy as the main subject. There was no time limit and theses, monographs, dissertations, review articles and repeated articles were excluded. After searching and refining the selection through the database filters, reading the titles and abstracts, 12 articles were selected to compose the results of this research.

\section{RESULTS}

The articles selected for the Integrative Review are shown in table 1.

\section{DISCUSSION}

After analyzing the articles, it was found that occupational therapists who have SIT certification, observed that children with dysfunctions in Sensory Integration have confused and disorganized language, reading and writing, which delays their school learning 
and hinders their interaction with other people. This difficulty at school is also discussed in the study by Campos, Silva and Ciasca ${ }^{[7]}$, where the importance of inclusive education for children with this type of demand is emphasized, as is the case of children with Autism Spectrum Disorder (ASD). When Sensory Integration Therapy was introduced, children began to present better communication, writing and articulation of words, in addition to improving social interaction with family and other children. Professionals often use the child's playfulness and intrinsic motivation during therapies, avoiding the feeling of failure when they are unable to perform any task initially proposed ${ }^{[8,9]}$.

TABLE 1. Articles selected for the Review

\begin{tabular}{|l|l|}
$\begin{array}{l}\text { YEAR OF } \\
\text { PUBLICATI } \\
\text { ON }\end{array}$ & TITLE \\
\hline 2019 & $\begin{array}{l}\text { Occupational } \\
\text { Interventions for Children and } \\
\text { Youth With Challenges in Sensory } \\
\text { Integration and Sensory } \\
\text { Processing: A School-Based } \\
\text { Practice Case Example }\end{array}$ \\
\hline 2019 & $\begin{array}{l}\text { Sensory integration therapy } \\
\text { versus usual care for sensory } \\
\text { processing difficulties in autism } \\
\text { spectrum disorder in children: } \\
\text { study protocol for a pragmatic } \\
\text { randomized controlled trial }\end{array}$ \\
\hline
\end{tabular}

Application of Data-Driven Decision Making Using Ayres Sensory Integration ${ }^{\circledR}$ With a Child With Autism

2016

2016

Sensory Integration Intervention in Children with Autistic Spectrum Disorder

2016

2016

2014

Occupational Therapy using the Sensory Integration approach: a single case study

Writing difficulties in the Chilean school context: Occupational Therapy approach and the use of Sensory Integration strategies Sensory Integration Functions of Children With Cochlear Implants

2013

2013

2012
PERIODIC

\section{AUTHORS}

\author{
The American CLARK, G. F; WATLING, R; PAHRAM, \\ Journal of L. D; SCHAAF, R. \\ Occupational \\ Therapy, v. 73, n. 3 , \\ p.1-8 \\ Biomedcentral, \\ e.20, v.113, p.1-11 \\ RANDELL, E.; MCNAMARAL, R; \\ DELPORT,S.; BUSSE, M. HASTING, R. \\ P.; GILLESPIEL, D.; WILLIAMS- \\ THOMAS, R.; BROOKES-HOWELL, L.; \\ ROMEO, R., BOADU, J.; AHUJA, A. S.; \\ MCKIGNEY, A. M.; KNAPP, M.; SMITH, \\ K.; THORNTON, J.; WARREN, G.
}

American Journal of Occupational

Therapy, v.70, n.1, p. 1-9

Chilean Journal of Occupational

Therapy, v.16, n.1, p. $99-107$

Chilean Journal of Occupational

Therapy, v.16, n.1, p. $115-124$

Chilean Journal of Occupational

Therapy, v.16, n.1, p. $57-68$

American Journal of Occupational

Therapy, v.68, n.5, p.562-569

FALLER, P., HUNT, J., VAN HOOYDONK, E., MAILLOUX, Z., SCHAAF, R.

COSTA, F. C. S.; PFEIFER, L. I.

JORQUERA, S.; ROMERO, D. M.

ÂNGULO, V.; ARENAS, D.

KOESTER, A.C; MAILLOUX, Z.; COLEMAN, G. G.;

MORI, A. B.; PAUL, S.M.; BLANCHE, E.; MUHS, J.A.;

LIM, D.; CERMAK, S. A.

American Journal of Occupational

Therapy, v.67, n.5, p..601-606

Occup. Ther. Int. RYOICHIRO IWANAGA, R.; HONDA, S. v.21, n.2014, p. 411

H.; NAKANE, H.; TANAKA, K.; TOEDA, H.; TANAKA, G.

American Journal of

SCHAAF, R.C.; HUNT, J.; BENEVIDES, Sensory Integration to Improve Occupational Sensory Integration to Improve Occupational T. 


\begin{tabular}{|l|l|l|l|}
\hline & $\begin{array}{l}\text { Participation of a Child With } \\
\text { Autism: A Case Report }\end{array}$ & $\begin{array}{l}\text { Therapy, v.66, n.5, } \\
\text { p. 547-555 }\end{array}$ & \\
\hline 2010 & $\begin{array}{l}\text { Perceptions of Occupational } \\
\text { Therapists on Language and } \\
\text { Communication of Children with } \\
\text { Sensory Integration Deficits }\end{array}$ & $\begin{array}{l}\text { Rev.Fac.Med. v.58, } \\
\text { n.4.263-271 }\end{array}$ & $\begin{array}{l}\text { OTERO, B. A.; ANGARITA, M.M.; } \\
\text { ARIAS, P.Z. }\end{array}$ \\
\hline 2005 & $\begin{array}{l}\text { Sensory Integration Deficit: Long- } \\
\text { term Effects on Occupation and } \\
\text { Play }\end{array}$ & $\begin{array}{l}\text { Chilean Journal of } \\
\text { Occupational } \\
\text { Therapy, n.5. }\end{array}$ & IMPERATORE, E. B. \\
\hline
\end{tabular}

Children who have difficulty in praxis, gross and / or fine motor coordination, as well as balance and postural control, benefit from SIT with activities with little or a lot of proprioceptive, tactile and vestibular information. In addition, there are activities that encourage the bilateral use of limbs in a coordinated manner, improving body awareness [10]. For praxis, specifically, activities with a high amount of sensory input were seen, which stimulate new motor planning, attention and motor dexterity using SIT specific equipment such as suspended nets, padded flat swings, vestibulator, etc., which resemble equipment parks, where the child uses the toy with a little help from the therapist or alone [6].

SIT is also widely used in cases of infant food selectivity. Food selectivity can be defined as the resistance, refusal or disinterest in eating some foods, causing the child's nutrients and energy to be limited and a decrease in the proper functioning of the organism [11]. This aversion to food, in these cases, can be sensory-based, so the integration of sensations can help the child organize the way information gets to him, thus increasing his repertoire of foods and decreasing the resistance to experiment. new textures and consistencies, which are the most difficult food characteristics for children with selectivity ${ }^{[6,11,12]}$.

With the increase in cases of ASD, studies have been intensified and many treatment possibilities to alleviate the conditions of autism have been tried and presented, including Sensory Integration Therapy. A case study carried out with two children diagnosed with ASD, showed that both had sensory peculiarities, such as: dislike walking barefoot or cutting nails, sensitivity to loud sounds, food textures, in addition to constant stereotypes, twists and jumps. After the SIT, it was seen that the sensitivity of the two children could be adequate, thus improving their performance in Activities of Daily Living, school and social interactions ${ }^{[3]}$.

The intervention through Sensory Integration Therapy was also analyzed in the treatment of children with difficulties in performing ADLs, as self-care, due to disorganized sensory processing. SIT helped the patient to correctly identify and direct the sensory information of his own body and facilitate his behavior, social interaction and well-being [13,14].

In addition, SIT has been shown to be effective in cases of children with ASD with difficulties in cognitive and sensorimotor skills, which directly influence the performance of their routine activities $^{[15]}$. Through the knowledge of Sensory Integration, it is possible to build a treatment plan with sensory interventions that may have resulted in children's motor functions ${ }^{[16]}$. Thus, the importance of a well-trained and properly certified Occupational Therapy professional to facilitate SIT and make it more and more known and with credibility in the scientific environment ${ }^{17}$ is highlighted.

It is important to emphasize that if the child has any other associated pathology, such as a hearing impairment, for example, the professional will have to be aware of possible differences in the result of the evaluations and, consequently, in the practical intervention ${ }^{[18]}$.

\section{CONCLUSION}

After the aforementioned data, the contribution and importance of the Sensory Integration Therapy becomes clear, as it has been 
increasingly considered and requested for the assistance to the child population. Ayres' studies remain alive after decades and act as a subsidy for several intervention possibilities, not only therapeutic-occupational, but also for other professionals who study this audience. With SIT, it is possible to combine the objectives of the appropriate treatment plan for the child with playfulness, which is essential at this stage of life and helps to engage in the activity. The possibilities of activities using this approach favor the neuropsychomotor development in childhood, in addition to facilitating a better performance in ADLs, routine activities, at school and in interpersonal relationships.

\section{REFERENCES}

[1]. AYRES, A. J. Overview In: AYRES, A. J. Sensory Integration and Learning disorders. Los Angeles, CA, 1972.

[2]. Cardoso NR; Blanco MB. Terapia de Integração Sensorial e Transtorno do Espectro Autista: Uma Revisão Sistemática de Literatura. Revista Conhecimento Online, a. 2019, 11(1).

[3]. Costa FCS; Pfeifer LI. Intervención de Integratión em niños com Transtorno del Espectro Autista. Revista Chilena de Terapia Ocupacional. 16(1): 99-107.

[4]. AYRES, A. J. General principles and methods of intervention In: AYRES, A. J. Sensory Integration and Learning disorders. Los Angeles, CA, 1972.

[5]. Miller LJ et al. Concept Evolution in Sensory Integration: A Proposed Nosology for Diagnosis. The American Journal of Occupational Therapy. 2007, 61(2): 135-140.

[6]. Jorquera A; Romero DM. Terapia Ocupacional utilizando el abordaje de Integración Sensorial: Estudio de caso único. Revista Chilena de Terapia Ocupacional, 2016, 16 (1): 115-124.

[7]. Campos CCP; Silva FCP; Ciasca SM. Expectativa de profissionais da saúde e de psicopedagogos sobre aprendizagem e inclusão escolar de indivíduos com Transtorno do Espectro Autista. Rev. Psicopedagogia, 2018, 35(106): 3-13.

[8]. Otero BA; Angarita MM; Arias PZ. Percepciones de terapeutas ocupacionales sobre el Lenguaje y la comunicación de los niños con déficit de Integración Sensorial. Rev.Fac.Med. 2010, 58(4):263-271.

[9]. Ângulo V; Arenas D. Dificultades de escritura en el contexto escolar chileno: abordaje de Terapia Ocupacional y la utilizacion de estrategias de
Integración Sensorial. Revista Chilena de Terapia Ocupacional, 2016, 16 (1): 57-68.

[10]. Imperatore EB. Déficit de Integración Sensorial: Efectos a largo plazo sobre la ocupación y el juego. Revista Chilena de Terapia Ocupacional, 2005, 5.

[11]. Rocha GSS et al Análise da Seletividade Alimentar de crianças com Transtorno do Espectro Autista. Revista Eletrônica Acervo Saúde, 2019, 24(538): 1-8.

[12]. Clark, G. F; Watling, R; Pahram, L. D; Schaaf, R. Occupational Therapy Interventions for Children and Youth With Challenges in Sensory Integration and Sensory Processing: A School-Based Practice Case Example. The American Journal of Occupational Therapy, 73(3):1-8.

[13]. Bellefeuille IB; Schaaf RC; Polo ER. Occupational Therapy Based on Ayres Sensory Integration in the Treatment of Retentive Fecal Incontinence in a 3-Year-Old Boy. American Journal of Occupational Therapy, 2013, 67 (5): 601-606.

[14]. Randell, E et al. Sensory integration therapy versus usual care for sensory processing difficulties in autism spectrum disorder in children: study protocol for a pragmatic randomized controlled trial. Biomedcentral, 2019, 20(113):111.

[15]. Ryoichiro Iwanaga R et al. Pilot Study: Efficacy of Sensory Integration Therapy for Japanese Children with High-Functioning Autism Spectrum Disorder. Occup. Ther. Int. 2013, 21(2014): 4-11.

[16]. Schaaf RC; Hunt J; Benevides T. Occupational Therapy Using Sensory Integration to Improve Participation of a Child With Autism: A Case Report. American Journal of Occupational Therapy, 2012, 66(5):547-555.

[17]. Faller, P. et al. Application of Data-Driven Decision Making Using Ayres Sensory Integration ${ }^{\circledR}$ With a Child with Autism. American Journal of Occupational Therapy, 70(1): 1-9.

[18]. Koester AC et al. Sensory Integration Functions of Children with Cochlear Implants. American Journal of Occupational Therapy, 2014, 68(5): 562-569. 